\title{
INDIAN BURIALS OF POTTAWATTAMIE COUNTY
}

By O. J. PRUITT

The only documented Indian village burial site in Pottawattamie county is that of the Otoe, seen by Lewis and Clark in 1804. After camping on the west shore of the Missouri river, and going one mile the next morning, so the statement runs, they came to the bluffs on the east side-the first time since leaving the Nodaway. A little way below was the old Otoe village, at that time abandoned, the Indians having gone to the Des Moines river. This site lies within the city limits of Council Bluffs and is now a part of Big Lake park. This park was so named from the meandering of the river in 1832 when the channel of the river moved nearly a mile west. In this manner it created the lake and also Carter lake in Nebraska. The village of Carter Lake, however, is in Iowa territory, although on the west bank of the river.

During the tenure in western Iowa of the Otoe, Iowa and Missouri Indians, many burials occurred. This tenure in all probability covered nearly a century. High on the bluff just south of the old village is the graveyard of these Indians, long since exploited by high school boys and relic hunters. The bluff is on land now owned by the Wickhams, at one time the property of the Mynsters, who traded goods for the land with the Mormons when they departed for Salt Lake. To the north is the land once owned by the late W. S. Cooper, sold by him to the park board to enlarge Big Lake park. When it was graded, hundreds of artifacts were found, and are yet being found after heavy rains.

Cooper's Bluff with a winding road, forms a part of a scenic drive to the Lewis and Clark monument, located at what is now known as Rainbow Point. Cooper's Point and the bluff to the south, site of the Otoe burial ground, constitute what is known as Hart's Bluff of early history. Cooper's Point was also a burial ground and in the yard of 
the old Cooper home are slabs of broken concrete that mark graves. These graves, Mr. Cooper told the writer, were disturbed at the time of grading, but lowered to, or re-entered at the exact spot of the original burial. Other skeletons were reburied higher on the bluff in a single grave. Mr. Cooper had a fine collection of Indian artifacts collected on the premises.

In Fairmont park on the east side of the city are more graves, many disturbed by grading, but a few are intact. This bluff is known as Monomotor Hill and has an elevation of 1177 feet above sea level.

\section{A Leaden Casket in Early Grave}

On the sites of the present Ogden hotel and the Calvin Hafer property were many graves of both Indians and whites. During excavation a half century ago, a leaden casket was found bearing the remains of an infant.

The Indian burial grounds of the proto historical period, and that of many Pottawattamie Indians, were located on the site of the Pierce Street school. Here were buried Chief Billy Caldwell (Sagonah) and Williamette. Their skeletons now rest in the Catholic cemetery and bear the simple marking of "Indian." Throughout the city human graves are occasionally encountered while excavating for house building.

Indian Bald Knob, referred to by Lewis and Clark, was the burial place of many Indians. Many of the graves were destroyed when the landslide occurred in 1915. At that time a great portion of the west side of the bluff slid and buried the tracks of the Chicago and Northwestern Railway. Traffic was stopped for days.

Indian Bald Knob is known as Stephen's Point and is on land owned by Charles Beno. Here to the east of the bluff is a canyon over a mile in length. At its mouth is the site of the village and trading post, Bad Heart, named after a Sioux Indian mentioned many times in history by Father DeSmet, Joseph LaBarge, General Atkinson, and others. This site is east of the Grand Battier of steamboat days, and today known as The Narrows. It 
is a sandbar of over a hundred acres. River improvement has nearly obliterated the great sandbar. East of the Bad Heart village site, on a bluff, are a few more graves of Indians. Beneath this bluff is an exposure of the Pierre shale, and a short distance below this exposure is that of the Aftonian sands. A large spring is in the immediate vicinity.

Going north along the bottom road, the next Indian burial ground is at Lime Kiln Hollow, where lime was burned for the building of Fort Atkinson in 1818-1819. Here W.P.A. workmen uncovered several skeletons while building a road. Halfway up the bluff and on the saddle are more graves, some exposed by the plow.

\section{ExCAVATIONS NORTH OF COUNCIL BLUFFs}

At Crescent, a village ten miles north of Council Bluffs, seven mounds were excavated by the late Doctor Gilder, Jack DeWitt, then a newspaper man, now a motion picture writer, two medical students, and the writer. In one of these mounds everything found showed pyral action and evidently was the burned dead of the Winnebagos from the smallpox epidemic of 1848. One mound gave up a jaw of a female showing supernumerary dentine. These mounds are the work of the Winnebagos and within historic times. One mound, however, proved to have subsequent burials, and at the time this was done, the mound was enlarged, thus burying deeper the first interred which had antiquity. Here at a seven-foot depth was found the skull of a male adult with beetle brow and a low crown. This skull was sent to Washington for classification. It is now exhibited in the Pottawattamie County Historical Museum. ${ }^{1}$ It was taken from among the roots of a scrub oak tree over one hundred fifty years old.

WHEEL BURIAL OF INDIANS

In the Pigeon river valley is a mound of huge proportions, being 800 feet long, 300 feet wide, and 25 feet

\footnotetext{
${ }_{1 M r}$. Pruitt, the writer of this narrative of exploration, is curator of the museum of the Pottawattamie County Historical Society, with museum in Lincoln Park, Council Bluffs. This work was done prior to 1942 .
} 
high. On the S. B. Peters farm immediately west of this mound was found the first wheel burial. Here all the heads were within a space three feet in diameter, the feet radiating like the spokes of a wheel. Others of this kind were found near Sol Smith's lake in Harrison county.

These wheel burials are quite interesting and merit much more study as to their origin and meaning. We really found four of this kind of burials. On the Peters farm, which is near Crescent, there were nine skeletons in the grave and all appeared to have had their heads bashed in presumably with a tomahawk. This was thought by all who saw the situation to have been the result of a battle between the Winnebagos and the Sioux in historic times. One such burial place in Harrison county, five miles above Missouri Valley, was opened by Charles Kelsey, and it is stated that one of the skeletons had a protuberance of horn-like appearance on the occupit which resembled that of the Kaffirs of South Africa which were allegedly removed by English surgeons during the Boer war to allay savagery. This is on authority of George S. Steinberg of Council Bluffs.

At Sol Smith's lake in Harrison county, Fred Yocum and the writer found another wheel burial with nine skeletons. Apparently these were warriors killed in battle. In a single grave we found the skeleton of another, minus the head and one hand. Three feet from the natural burial of this, we found the skull with jaw intact and some shell beads. The missing finger bones from the hand were also found in this place. An attempt had been made to burn the skull, jaw and fingers. In the grave proper we found the femurs. One of these showed there had been a compound fracture in life and that there had been perfect surgery in the setting of the bone. As both bones were of the same length it was the opinion of the late Dr. McCrea that the subject walked without a limp and that the break had occurred long before the decease of the subject. These specimens are now in the Pottawattamie Historical Museum, along with many other human bones. 
A bear effigy mound of nearly the above dimensions is to be seen on the farm of Mr. Singafoos along Honey creek. It is on a high hill and is thought to have been the work of the Winnebagos. Still further north and atop the bluff near Loveland are many graves discovered in 1939.

\section{ANimal Skeletons Found}

Perhaps as a diversion, and in order to portray some idea of the geology of the bluffs, it will be of interest to tell of some animal skeletons found from time to time. One skeleton of a bison was found in a standing position on the leeward side of a bluff when excavation was going forward for house building. Another was found in the vicinity of Loveland on the onward side of the bluff. It, too, was in an upright position. This came to light when a hunter dug for a fox whose den was beneath.

Geologists state that this type of bison perished at the time of the Kansan visitation, with the runoff of the water, and that the position was accidental. This explanation seems fair in view of the fact others were found in other positions. The scientists refuse to believe these animals were so dumb as to stand still and be covered by the wind-blown loess.

The writer spent years in charting and mapping Indian burial grounds, villages and camp sites. During his engagement as a writer for the "Writers' Guide" in 1935 he compiled and mapped all the ancient Indian trails, the old Mormon locations, and those of the prehistoric dwellers. The homes of these dwellers were underground caverns, often connected by tunnels for intercommunication and exit. In these caverns were found the bones of the giant ground sloth, teeth of the hairy mammoth, and the crudest of pottery and flints. These, however, are in an adjoining county.

In historic times Big Foot, chief of the Ottawa, had a village at the confluence of Indian creek and the East Nishnabotna river. His tribe hunted the lands west of the river of the same name. Here near the site of the old Mormon town of Macedonia he maintained a camp dur- 
ing this ten years' sojourn. Many of his dead were buried on the B. F. Clayton farm in what was then a forest. On the same farm and near the old mill (built by Stutsman, and operated within the memory of the writer by Pruden and Carter) are more Indian graves.

At Oakland is another Indian burial ground not investigated by the writer. The report of Mr. McArthur, a collector of repute is accepted as to this fact. Along the streams of the county may be found camp sites once used by hunting parties. Three exist along Keg creek, all within the county.

A burial ground near the old Bibi Camp in Boomer township has not as yet been investigated. It is thought to be entirely historic as that section was occupied by the Winnebagos during Bibi's sojourn and eventful trip west.

The Mandans in Western Iowa

Here and there in the bottoms are found the very first of the known Indians to pass up the river, the Mandans. Very few mortuary offerings are found intact in the mounds, and all are natural burials. The Mandans, however, buried all the deceased's belongings with the dead. They chose for the places of burial a sand dune of water deposition. These are remarkably preserved and often found intact, articulated, and insitto. The preservation is due to the presence of nonacid soil and the subsequent aggrading of the lands from flood periods of the Missouri river. They are found at ten to twelve feet depth, and this is one reason so little is known of the Mandans and the locations of their villages. Deep sites accredited to a more ancient people may be those of the Mandan during their tenure.

At the Snyder gulch site just north of Missouri Valley in Harrison county, the ash stratum varies in width from 12 inches to nothing for a distance of 75 feet, and is some twelve feet from the surface and the Gilmore site on the Nebraska side is of about the same depth. Burials in the loess are badly decomposed, even those of historic times. Many of the Otoe burials are flexed, but in all the mounds 
the skeletons, while not oriented, are usually found to be natural, though some are with face down. Perhaps the most curious burials are those of the Pawnee, in sitting posture, and found in an adjoining county.

Pathetic finds are made in some of the mounds. Sometimes a mother with a babe in arms is found. In other places are found headless skeletons and some without legs. Others have dogs, and others horses, in the graves. One grave was opened in the Honey creek area with the skeleton showing the deceased had been buried astride his faithful steed. A long trench had been dug, the horse tethered by foot to oak stakes and the Indian tied to the horse and all covered. In times past, animals had uncovered the skull of the horse and it was missing, but all other bones of the horse and man were found. Also bits of cloth, colored feathers, pipe, an old Colt's pistol, some flint arrowheads, and a half dollar dated 1838.

The greatest mystery was discovered in an adjoining county when the writer was taken by Charles Kelsey to a canyon named Squaw Gulch. Here at a depth of eight feet in a wash, were found skulls, leg and arm bones of more than forty female adults and but one male. These were water strewn for a distance of a hundred yards. At the head of the gully was found an earthen house site bisected by the wash. There was some evidence of a landslide, but how may one account for so many female skulls and but a single male? The male was that of an adolescent with the eighteen-year molar just arising.

\section{A Rich FIND OF GOLD}

Farther north along Allen creek, some five miles long, are to be seen three different formations divided with humus strata. The last strata are presumed to be the result of a huge landslide. The conglomeration of debris, artifacts, and human skulls and bones goes far to substantiate the theory of a slide. It happened long ago, before the advent of the whites as evidenced by trees exceeding one hundred fifty years in age by ring count covering much of the valley and canyon. It is located on 
a four hundred-acre timbered game and bird reserve. High on a hill to the north of the valley and canyon and forming an arc with the contour of the land are five distinct mounds. The timber was removed from the site and the land put under cultivation a few years ago. Here we did a lot of digging, knowing that with a few years of farming, the plow would eventually destroy the evidence. My assistants were the two Larsen brothers and Jack DeWitt. We chose the second from the south and carried the work forward until we found the number of skeletons indicated by the ash stratum, in the center and near the top. Thinking we had the work for this particular mound complete, we abandoned it for another. Two local amateurs found an intrusive burial of very recent date. It was a rich find: two gold twenty-dollar pieces drilled for ear rings, an old Colt's cap-and-ball pistol, a leather moneybelt with a few coins of the fifty's vintage, a gold watch and chain, a butcher knife, beads, and a watch charm of agate.

Let us return to burials found within the city. One laborer relates that he dug up while excavating a basement, three skeletons of Indian women with the dresses and beads in a fair state of preservation. In the same place he found a cache of arrowheads made of the Nehawka flint. This same laborer, James Stokesbury, told of many finds all in the bottomlands and in sand. A few years ago he called the writer to view some bones taken from a trench dug for the laying of waterpipe. Here in a sand stratum were the bones of an almost complete skeleton of a bison more than a century old. In corroboration of the above find we have the story of Robert Rain, an old contractor of the early days of the city. He once built a beer-cooling cave for the Conrad Giese brewery. It penetrated the bluff for nearly a hundred feet, and at a depth of thirty feet he found a stone ax. This cave was destroyed a few years ago when it became a menace. William Wilbur had a son die in the cave, from exhaustion and the foul air, aggravated by an over-indulgence of green apples. 


\section{Bisons AND Stone AXES}

Robert Rains, Jr., was the finder of the bison in an upright position on Logan street just west of Mercy hospital. East of the city, and on the leeward side of a bluff, a man whose name is lost to history unearthed two huge ceremonial stone axes weighing respectively thirteen and one-half and fourteen pounds. They were exhibited at the Chicago Columbian Exposition in 1893 and were lost to the county until very recently. Mr. McArthur, elsewhere mentioned, found them in the Field Museum and traded for them some very excellent Mexican pottery and some pottery icons of an early Mexican ruler, believed to have great antiquity. Mr. McArthur spent several years in old Mexico in the mining business and was greatly interested in collecting historical articles. In his home in Oakland is the largest and finest collection of Indian artifacts to be seen in the county.

Near Neola, an old village site buried more than eight feet by the floods of Mosquito creek, on the Poloski farm, the Abbott Grove of early history, is a graveyard used by the Indians. John Newland, a geologist and collector, lives at Neola. He is the finder of the giant horns of the ancient Wapti, said to be at Iowa City.

At the Charles Thomas place in Boomer township, and also on the farm of Nels Jensen in the same township are other camp sites. Early types of Algonquin artifacts are found along North Pigeon creek. Much of the material from this place is of Ohio flint stone. The native flint is of a blue-gray color with diatoms, included with other larger creatures. Near flint or clinker stone is black, while some of the flints shade to reds, brown, tan, and pink. Very little pure white chert is found. Green stone was used by the Winnebagos for buffalo lance points and those are six inches long by one and a half inches wide. Only one white chert has been found in the county. It was unearthed at Big Lake.

This recital would be too long if we should go into detailed description of the potsherds found, or should at- 
tempt to set forth the order of the various tribes who have inhabited this territory. In the classification of the Indian graves of the county we have related only that which we have found and seen many times. Our experience covers a quarter of a century of field work in the company of noted scientists. We are fortified with a complete library of the issues of the Bureau of American Ethnology publications, monographs of noted men and reports of the Midwest Archaeological Association, as well as the writings of Doctor Strong, Gilder, and many others. In no case have we ventured an opinion without full concurrence of others more experienced.

\section{PEOPLE OF THE PLACE OF FIRE}

Much has been published in this journal and elsewhere about the Indians for whom one of Iowa's largest counties was named. The name of the county is spelled Pottawattamie, and this spelling has been followed in Iowa for the Indians as well. It is interesting, however, to note that what might be called the official spelling for the tribe, as used in publications of the United States, is Potawatomi. This is said to be nearest to the name as spelled by those who best knew the tribe. But there has been a great variety of spellings.

A writer who spoke the language of the related tribes gave it out that the original spelling should have been Potawatamink, which translated means the "People of the Place of Fire." These Indians were referred to in the Jesuit Relations as one of four nations residing on the west shore of Lake Huron. The Maskotens (Muscatines), or fire nation, seem to have been related. The Potawatomi took part in some thirty treaties with the United States, commencing in 1789 , or were referred to in treaties with various nations. When these treaties were printed by the Indian bureau, the spelling in the various headings was always Potawatomi, though in the body of the treaty other spellings were used. 
Copyright of Annals of Iowa is the property of State of Iowa, by \& through the State Historical Society of Iowa and its content may not be copied or emailed to multiple sites or posted to a listserv without the copyright holder's express written permission. However, users may print, download, or email articles for individual use. 